\title{
EDUKASI GIZI TERHADAP PENGETAHUAN DAN KEBIASAAN JAJAN PADA SISWA SMP NEGERI 35 MAKASSAR
}

\author{
Asmarudin Pakhri ${ }^{1}$, Chaerunimah ${ }^{1}$ dan Rahmiyati $\mathbf{R}^{\mathbf{2}}$ \\ ${ }^{1}$ Jurusan Gizi, Politeknik Kesehatan Kemenkes, Makassar \\ ${ }^{2}$ Alumni Prodi D-IV, Jurusan Gizi, Politeknik Kesehatan Kemenkes, Makassar \\ Korespondensi, email : asmarudinpakhri@poltekkes-mks.ac.id
}

\begin{abstract}
One effort to increase knowledge is to educate health about nutrition especially. Nutrition education is essentially an activity to deliver a health message to a community or group in the hope of influencing the behavior of the target. The habit of snacking is part of the action-shaped behavior that becomes a pattern of the behavior of a person or group that tends to be difficult to change. This study aims to determine the effect of nutritional education on knowledge and habits of jajan at students of SMP Negeri 35 Makassar. The type of research is pre experimental study with one group pre-test and post-test design. The location of the research was conducted at SMP Negeri 35 Makassar. Samples are students of class VIII of 100 students obtained by simple random sampling. The study was conducted on April 8 - April 22, 2017. The results are presented in tabular and narrative form. Based on the results of research conducted at SMP Negeri 35 Makassar shows that the knowledge of students before given less than 58\% of good nutrition education and good (42\%) using Wilcoxon statistical test obtained value $(p=0,000)$ which means there is influence of education Nutrition to knowledge in students. In the habit of snack before given nutrition education that is as much (63\%) and good as much (37\%), using Wilcoxon statistic test obtained value ( $p=0,372)$ which means there is no effect of nutritional education to snack habits on students. Nutrition education with reverse sheet media shows there is an influence on knowledge but there is no effect on the snack habits.
\end{abstract}

Keywords: Knowledge, Nutrition Education, Pocket Habits

\section{PENDAHULUAN}

Remaja adalah golongan usia sekolah yang merupakan generasi penerus bangsa, dimana kualitas bangsa dimasa depan ditentukan kualitas remaja saat ini. Dalam masa tumbuh kembang remaja diperlukan perhatian khusus dalam mengonsumsi makanannya (Judarwanto, 2004). Namun keadaan gizi remaja sebagian belum menggembirakan. Hasil Riskesdas tahun 2013 menunjukan sebagian remaja kurang gizi yaitu kurus $11 \%$ dan pendek 35\%. Disamping itu sebagian remaja $(10,8 \%)$ kelebihan gizi (Balitbangkes, 2013). Di samping itu asupan gizi remaja juga masih kurang. Penelitian Hatta (2014) pada siswa SMPN 35 Makassar mendapatkan asupan energi dan protein sebagian siswa kurang (63,3\%). Penelitian Hendrayati, dkk, 2010 di SMP Tompobulu Bantaeng mendapatkan asupan energi dan pola 
makan siswa sebagian masih kurang (52,1\% dan $96,9 \%)$.

Penyebab masalah gizi pada remaja meliputi bebarapa hal antara lain pemahaman gizi yang keliru, kebiasaan makan yang buruk, kebiasaan makan tertentu yang berlebihan dan promosi makanan siap saji yang berlebihan (Adriani dan Wirjatmadi, 2012). Kurangnya pemahaman gizi dan kebiasaan makan dapat dilihat dari hasil penelitian. Penelitian Salmiah, dkk (2015) pada SMPN 35 Makassar mendapatkan pengetahuan gizi sebagian remaja 64,3\% masih kurang. Penelitian Fauzi, 2012 pada SMPN 107 di Jakarta mendapatkan pengetahuan siswa tentang makanan sumber zat besi masih kurang.

Faktor lain yang mempengaruhi masalah gizi remaja adalah kebiasaan jajan yang belum sehat. Jajanan merupakan bagian yang tidak terpisahkan dari kehidupan manusia. Pangan jajanan diharapkan selain harga yang murah dan jenisnya yang beragam, juga menyumbangkan kontribusi yang cukup penting akan kebutuhan gizi. Anak sekolah sangat menyukai pangan jajanan. Para pedagang berupaya untuk memberikan penampilan yang menarik dan rasa yang disenangi anak-anak dengan menambahkan bahan-bahan tertentu tanpa memedulikan keamanannya (Rina, 2007).

Makanan jajanan menurut FAO (Food and Agriculture Organization) adalah makanan dan minuman yang dipersiapkan dan dijual pedagang kaki lima di jalanan dan di tempat-tempat keramaian umum lain yang langsung dimakan atau dikonsumsi tanpa pengolahan atau persiapan lebih lanjut (Khomsan, 2004). Menurut Wahyuti dalam Febianty (2009), kebiasaan jajan adalah bagian dari perilaku berbentuk tindakan yang menjadi suatu pola dari tingkah laku seseorang atau kelompok yang cenderung sulit untuk berubah.
Berdasarkan penelitian yang dilakukan oleh Putra (2009) mengenai kebiasaan jajan siswa menunjukkan bahwa sebagian besar siswa $(98,7 \%)$ mengonsumsi jajanan di sekolah, rata-rata siswa menghabiskan uang sebesar Rp.5.090,91 perhari untuk membeli makanan jajanan, sebanyak $(72,7 \%)$ beresiko tinggi mengandung bahaya, ratarata siswa jajan 2 kali dalam sehari pada waktu istirahat sekolah, sebanyak $(42,3 \%)$ siswa jarang mencuci tangan sebelum makan dan $35,9 \%$ siswa pernah sakit setelah mengonsumsi jajanan.

Meskipun makanan jajanan memiliki keunggulan-keunggulan dalam menyumbang kecukupan gizi remaja setiap harinya, namun makanan jajanan di sekolah ternyata sangat beresiko terhadap kesehatan karena penanganannya sering tidak higienis yang memungkinkan makanan jajanan terkontaminasi oleh mikroba beracun maupun penggunaan bahan tambahan pangan (BTP) yang tidak diizinkan (Mudjajanto, 2005).

Pada penelitian yang dilakukan suatu lembaga studi di daerah Jakarta Timur mengungkapkan bahwa jenis jajanan yang sering dikonsumsi oleh anakanak sekolah adalah lontong, otak-otak, tahu goreng, mie bakso dengan saus, ketan uli, es sirop dan cilok. Berdasarkan salah satu hasil uji laboratorium terhadap sirop merah positif mengandung rhodamin $\mathrm{B}$ (Judarwanto, 2004).

Salah satu cara untuk meningkatkan pengetahuan seseorang yaitu dengan cara memberikan edukasi gizi. Edukasi gizi ini dapat diberikan melalui penyuluhan, pemberian poster dan leaflet pada anak sekolah. Penelitian yang dilakukan oleh Nuryanto, dkk (2014), menunjukkan bahwa ada perbedaan rerata persen pengetahuan anak antara sebelum dengan setelah pendidikan gizi, dimana rerata pengetahuan gizi sebelum diberi pendidikan gizi sebesar 66,5 (9,3\%) naik menjadi 71,6 (9,6\%). Berdasarkan uraian 
diatas, peneliti tertarik melakukan penelitian mengenai pengaruh edukasi gizi terhadap pengetahuan dan kebiasaan jajan pada siswa SMP Negeri 35 Makassar.

\section{METODE}

Jenis penelitian adalah studi pra eksperimen dengan rancangan one group pre-test and post-test design. Untuk mengetahui pengaruh edukasi gizi terhadap pengetahuan dan kebiasaan jajan pada siswa SMP Negeri 35 Makassar. Edukasi gizi dilakukan dengan metode ceramah tanya jawab menggunakan media lembar balik sebanyak 3 kali (tiap minggu sekali) dengan materi: Pengertian, manfaat dan jenis jajanan, bahaya keamanan pangan pada jajanan, ciri-ciri dan contoh jajanan yang sehat dan tidak sehat, dampak konsumsi jajanan yang tidak sehat. Penelitian ini dilaksanakan pada sekolah SMP Negeri 35 Makassar pada bulan Agustus 2016 - Mei 2017. Populasi dalam penelitian ini adalah seluruh siswa kelas VIII SMP Negeri 35 Makassar. Sampel dalam penelitian ini adalah sebanyak 100 siswa.

Pengumpulan data dilakukan dengan dua cara yaitu data primer dan data sekunder. Data primer meliputi pengetahuan dan kebiasaan jajan yang diperoleh dengan menyebarkan angket, sedangkan data edukasi gizi diperoleh dengan pengamatan. Data Sekunder meliputi Data tentang gambaran lokasi penelitian atau data geografi dicatat dari dokumen pada instansi terkait di wilayah penelitian. Pengolahan data diolah dengan menggunakan program SPSS For Windows. Analisis data menggunakan Uji Wilcoxon untuk mengetahui pengaruh edukasi gizi terhadap pengetahuan dan kebiasaan jajan pada siswa SMP Negeri 35 Makassar.

\section{HASIL DAN PEMBAHASAN Gambaran Umum Lokasi}

SMP Negeri 35 Makassar terletak di Jl. Telegraf Utama Kelurahan Paccerakkang No. 1 Kecamatan Biringkanaya Kota Makassar, memiliki guru sebanyak 46 orang yang terdiri dari lulusan S3/S2 sebanyak 7 orang, S1 sebanyak 39 orang dan memiliki pegawai tata usaha sebanyak 17 orang yang terdiri dari lulusan S1 sebanyak 9 orang, Diploma sebanyak 2 orang, SMA/sederajat sebanyak 6 orang. Ruang kelas sebanyak 22 , ruang laboratorium IPA 1 , Ruang BK 1 , ruang staf tata usaha 1 , ruang guru 1 , perpustakaan 1, UKS (Unit Kesehatan Sekolah) 1, ruang keterampilan 1, ruang komputer 1, mushollah 1 dan kantin 2 . Jumlah keseluruhan siswa sebanyak 882 siswa yang terdiri dari kelas VII sebanyak 261 siswa, kelas VIII 297 siswa dan kelas IX sebanyak 323 siswa.

\section{Pengaruh Edukasi Gizi terhadap Pengetahuan}

Tabel 1

Pengetahuan Sebelum dan Sesudah Edukasi Gizi di SMP Negeri 35 Makassar

\begin{tabular}{ccccc}
\hline \multirow{2}{*}{ Pengetahuan } & \multicolumn{2}{c}{ Sebelum } & \multicolumn{2}{c}{ Sesudah } \\
\cline { 2 - 5 } & $\mathrm{n}$ & $\%$ & $\mathrm{n}$ & $\%$ \\
\hline Baik & 42 & $42 \%$ & 79 & $79 \%$ \\
Kurang & 58 & $58 \%$ & 21 & $21 \%$ \\
\hline Total & 100 & $100 \%$ & 100 & $100 \%$ \\
\hline
\end{tabular}


Hasil penelitian menunjukkan pada tabel 1 bahwa hasil pengetahuan sebelum dilakukan edukasi gizi yang baik sebanyak 42 orang $(42 \%)$ dan kurang sebanyak 58 orang $(58 \%)$, sedangkan pengetahuan sesudah edukasi gizi yang baik sebanyak 79 orang $(79 \%)$ dan kurang sebanyak 21 orang $(21 \%)$.

Tabel 2

Pengaruh Edukasi Gizi Terhadap Perubahan Pengetahuan Sebelum dan Sesudah Edukasi Gizi di SMP Negeri 35 Makassar

\begin{tabular}{|c|c|c|c|c|c|c|}
\hline Variabel & & $\mathrm{n}$ & & & & \\
\hline \multirow{4}{*}{ Pengetahuan } & & & Min & Max & $\mathrm{Z}$ & $p$ \\
\hline & & & - & + & & \\
\hline & Sebelum & 100 & 1 & 9 & \multirow{2}{*}{$-6,211^{a}$} & \multirow{2}{*}{0,000} \\
\hline & Sesudah & 100 & 2 & 10 & & \\
\hline
\end{tabular}

Hasil penelitian menunjukkan pada tabel 2 bahwa ada pengaruh edukasi gizi terhadap perubahan pengetahuan sebelum dan sesudah dengan nilai $(p=0,000<$ 0,05 ).

\section{Pengaruh Edukasi Gizi Terhadap Kebiasaan Jajan}

Tabel 3

Perubahan Kebiasaan Jajan Sebelum dan Sesudah Edukasi Gizi di SMP Negeri 35 Makassar

\begin{tabular}{ccccc}
\hline \multirow{2}{*}{ Kategori } & \multicolumn{4}{c}{ Kebiasaan Jajan } \\
\cline { 2 - 5 } & \multicolumn{2}{c}{ Sebelum } & \multicolumn{2}{c}{ Sesudah } \\
\cline { 2 - 5 } & $\mathrm{n}$ & $\%$ & $\mathrm{n}$ & $\%$ \\
\hline Baik & 37 & $37 \%$ & 46 & $46 \%$ \\
Kurang & 63 & $63 \%$ & 54 & $54 \%$ \\
\hline Total & 100 & $100 \%$ & 100 & $100 \%$ \\
\hline
\end{tabular}

Hasil penelitian menunjukkan pada tabel 3 bahwa hasil Kebiasaan Jajan sebelum dilakukan edukasi gizi yang baik sebanyak 37 orang (37\%) dan kurang sebanyak 63 orang (63\%), sedangkan pengetahuan sesudah edukasi gizi yang baik sebanyak 46 orang (46\%) dan kurang sebanyak 54 orang $(54 \%)$. 
Tabel 4

Pengaruh Edukasi Gizi Terhadap Perubahan Kebiasaan Jajan Sebelum dan Sesudah Edukasi Gizi di SMP Negeri 35 Makassar

\begin{tabular}{|c|c|c|c|c|c|c|}
\hline Variabel & & $\mathrm{n}$ & & & & \\
\hline \multirow{4}{*}{$\begin{array}{c}\text { Kebiasaan } \\
\text { Jajan }\end{array}$} & & & Min & Max & $\mathrm{Z}$ & $p$ \\
\hline & & & - & + & & \\
\hline & Sebelum & 100 & 1 & & \multirow{2}{*}{$-0,893^{a}$} & \multirow{2}{*}{0,372} \\
\hline & Sesudah & 100 & 1 & 10 & & \\
\hline
\end{tabular}

Hasil penelitian menunjukkan pada tabel 4 bahwa tidak ada pengaruh edukasi gizi terhadap perubahan kebiasaan jajan sebelum dan sesudah dengan nilai ( $p=$ $0,372>0,05$ ).

\section{PEMBAHASAN}

Pada penelitian ini diberikan edukasi gizi dengan metode ceramah dan tanya jawab menggunakan media lembar balik sebanyak 3 kali selama 3 minggu (1 kali seminggu) dengan materi, minggu pertama: pengertian, manfaat dan jenis jajanan, bahaya keamanan pangan pada jajanan, minggu kedua: ciri-ciri dan contoh jajanan yang sehat dan tidak sehat, minggu ketiga: dampak konsumsi jajanan yang tidak sehat. Sebelum diberi edukasi terlebih dahulu diberikan pre test lalu diberi edukasi setelah edukasi diberi post test dengan jumlah sampel sebanyak 100 siswa kelas VIII.

Pengetahuan siswa sebelum diberikan edukasi gizi yang kurang sebanyak $(58 \%)$ dan yang baik sebanyak (42\%). Hal ini sejalan dengan penelitian yang dilakukan oleh Achmadi (2015) yang menunjukkan bahwa sebelum diberikan edukasi gizi memiliki tingkat pengetahuan yang kurang yaitu sebanyak $(63,0 \%)$. Pada hasil penelitian setelah diberikan edukasi gizi mengalami peningkatan yaitu sebanyak (79\%), dengan menggunakan uji statistic Wilcoxon diperoleh nilai $(p=0,000$ $<0,05)$ yang artinya ada pengaruh edukasi gizi terhadap pengetahuan pada siswa SMP Negeri 35 Makassar. Hal ini sejalan dengan penelitian yang dilakukan oleh Candra, dkk (2013) yang menunjukkan bahwa terdapat perubahan pengetahuan setelah pemberian edukasi gizi terhadap tingkat pengetahuan jajanan sehat sebelum dan sesudah dengan nilai $(p=0,05)$.

Kebiasaan jajan sebelum diberikan edukasi gizi yaitu sebanyak (63\%) dan yang baik sebanyak (37\%). Hal ini sejalan dengan penelitian yang dilakukan oleh Saputri (2012) yang menunjukkan bahwa sebelum diberikan edukasi gizi memiliki tingkat pengetahuan yang kurang yaitu sebanyak $(83,3 \%)$ Pada hasil penelitian setelah diberikan edukasi gizi mengalami peningkatan tetapi peningkatannya hanya sedikit yaitu hanya (46\%) dengan menggunakan uji statistic Wilcoxon diperoleh nilai $(p=0,372>0,05)$ yang artinya tidak ada pengaruh setelah pemberian edukasi gizi terhadap kebisaan jajan pada siswa SMP Negeri 35 Makassar. Hal ini sejalan dengan penelitian yang dilakukan oleh Nurhasanah, dkk (2014) yang menunjukkan bahwa tidak terdapat pengaruh setelah pemberian edukasi gizi terhadap kebiasaan jajan siswa sebelum dan sesudah dengan nilai $(p=0,480<$ 0,05).

\section{KESIMPULAN}

1. Edukasi gizi yang diberikan kepada siswa dengan metode ceramah dan 
tanya jawab menggunakan media lembar balik sebanyak 3 kali selama 3 minggu (1 kali seminggu).

2. Pengetahuan siswa SMP Negeri 35 Makassar sebelum edukasi yaitu kurang (58\%). Hasil uji statistic Wilcoxon menunjukkan ada pengaruh edukasi gizi terhadap pengetahuan pada siswa SMP Negeri 35 Makassar ditunjukkan dengan nilai $(p=0,000<0,05)$.

3. Kebiasaan jajan siswa SMP Negeri 35 Makassar sebelum edukasi yaitu kurang (63\%). Hasil uji statistic Wilcoxon menunjukkan tidak ada pengaruh edukasi gizi terhadap kebiasaan jajan pada siswa SMP Negeri 35 Makassar ditunjukkan dengan nilai $(p=0,372>$ 0,05).

\section{SARAN}

Diharapkan kepada guru untuk memantau makanan yang dijual di kantin sekolah dan penjual makanan di lingkungan sekolah agar lebih sehat dan aman untuk dikonsumsi, memberlakukan peraturan kepada penjual dikantin dan penjual makanan di lingkungan sekolah agar sesuai syarat-syarat kesehatan serta meningkatkan kesadaran siswa untuk tidak mengkonsumsi makanan jajanan sembarangan guna memperkecil jumlah gangguan kesehatan pada anak sekolah.

\section{DAFTAR PUSTAKA}

Adriani, M dan Wirjatmadi, 2012. Peranan Gizi dalam Siklus Kehidupan. Kencana Prenadamedia, Jakarta.

Balibangkes Depkes RI, 2013. Hasil Riset Kesehatan Dasar Tahun 2013.

Candra AA, Setiawan B, Damanik HM. (2013). Pengaruh Pemberian Makanan Jajanan Pada Siswa Sekolah Dasar. Jurnal Gizi dan Pangan. Volume 8 (2)

journal.ipb.ac.id/index.php/jgizipangan/arti cle/viewFile/.../5949

Fauzi, CA, 2012. Analisis Pengetahuan dan Perilaku Gizi Seimbang
Menurut Pesan ke 6, 10, 11 dan 12 Pedoman Umum Gizi Seimbang pada Remaja. Journal Kes. Reproduksi, Vol 3 No. 2, Agustus 2012, 91-105

Febianty F. 2009. Hubungan Kebiasaan Jajan, Karakteristik Anak Serta Karakteristik Orang Tua dengan Status Gizi Anak Sekolah Di SDN Rawajati 03 Pagi Jakarta Selatan. FKM UI. Jakarta; Universitas Indonesia.

Hatta (2014). Asupan Energi dan Protein Siswa SMP Negeri 35 Makassar. KTI Jurusan Gizi.Politeknik Kesehatan Makassar.

Hendrayati, 2010. Pengetahuan Gizi, Pola Makan dan Status Siswa SMPN 4 Tompobulu Bantaeng. Media Gizi Pangan, Vol. IX, Ed 1 JanJun 2010

Judarwanto W. (2004). Perilaku Makan Anak Sekolah. [Online]. Available:http//www.gizi.net/ma $\mathrm{kalah} /$ download/perilaku\%20ma kan\%20anak\%20sekolah.

Df[Diakses 4 September 2016]. Picky Eaters Clinic.

Khomsan A. (2004). Pangan dan Gizi Untuk Kesehatan. Jakarta; PT. Raja Grafindo Persada.

Mudjajanto ES. (2005). Keamanan Makanan Jajanan Tradisional. [Online]107Available:http://ww w.gizi.net/cgibin/berita/fullnews. cgi?newsid1108963004,1393[Ac cessed on September 3, 2016].

Nurhasanah A, Sofyan NS, Resnayati Y. (2014). Pengaruh Pendidikan Gizi Terhadap Peningkatan Pengetahuan, Sikap dan Perilaku Tentang Jajanan Sehat Pada Murid Sekolah Dasar. Skripsi. Jurusan Keperawatan Poltekkes Kemenkes Jakarta III. ejurnal.poltekkesjakarta3.ac.id/i ndex.php/JKEP/article/view/.../3 $\underline{6}$ 
Nuryanto, Pramono A, Puruhita N, dkk. (2014). Pengaruh Pendidikan Gizi Terhadap Pengetahuan Dan Sikap Tentang Gizi Anak Sekolah Dasar. Jurnal Gizi Indonesia. Volume 3(1).

Putra AE. (2009). Gambaran Kebiasaan Jajan Siswa Di Sekolah Dasar Hj.Isriati Semarang. Artikel penelitian. Universitas Diponegoro Semarang.

Rina. (2007). Persepsi Orang Tua dan Guru Terhadap Keamanan Pangan Jajanan Anak Sekolah Dasar di Kota Bogor. Skripsi. Institut Pertanian Bogor.

Salmiah, Siti Nur Rochimiwati, Ramlan Asbar dan Nurliya Amir, 2015. Gambaran Remaja Obesitas tentang Pengetahuan Pola Menu Seimbang di SMPB 30 Makassar. Media Gizi Pangan, Vol. XIX, Ed 1, 2015

Saputri LO, Kristiawati, Krisnana I. (2012). Peningkatan Pengetahuan dan Sikap Dalam Pemilihan Jajanan Sehat Menggunakan edukasi gizi di sekolah dasar. Skripsi. Fakultas Keperawatan Universitas Airlangga Kampus C Mulyorejo Surabaya 60115 